\title{
Journal of Recent Advances in Medicine
}

\section{The possible ameliorative effect of carnosine in protein deficient diet induced testicular damage}

\author{
Omneya M. Kamel ${ }^{1 *}$, Basma K. Ramadan², Azza H. Abd Elwahab², Somaia M. Mohamed ${ }^{2}$, Hasan S. Ali ${ }^{3}$ \\ ${ }^{1}$ Physiology Department, School of Medicine, Newgiza University, Giza, Egypt \\ ${ }^{2}$ Physiology Department, Faculty of Medicine for Girl, Cairo, Al-Azhar University, Egypt \\ ${ }^{3}$ Histology, Faculty of Medicine for Boys, Cairo, Al-Azhar University, Egypt
}

\section{ABSTRACT}

Background: Malnutrition due to protein deficiency is an emerging problem worldwide particularly in the developing countries. Reproductive system development and growth depends on maintaining healthy nutrition especially in childhood and adolescence.

Objective: The present study aims at studying the possible protective efficacy of carnosine in testicular atrophy, defective spermatogenesis and reduced reproductive performance induced by supplementation of protein deficient diet (PDD) to male rats.

Methodology: Forty juvenile male albino rats were allocated into four equal groups; each group is 10 rats (i) normal control rats, (ii) protein deficient diet (PDD) group (received PDD for 75 days and saline intraperitoneal (IP) 5 days/week), (iii) carnosine (CAR) group (received carnosine $250 \mathrm{mg} / \mathrm{kg}$ body weight (bw), IP 5 days/week for 75 days); (iv) CAR-PDD group (received PDD for 75 days and carnosine $250 \mathrm{mg} / \mathrm{kg}$ body weight (bw), IP 5 days/week).

Results: PDD supplementation lead to decreased body and testicular weights, reduced sex hormones and sperm count, motility and vitality (Live: Death ratio). In addition, the PDD-treated group had decreased levels of the antioxidant enzymes as reduced catalase (CAT) and glutathione (GSH) levels in testicular tissue. These toxic effects were accompanied by elevation of the pro-inflammatory cytokines, tumor necrosis factor-alpha (TNF- $\alpha$ ). Increased proapoptotic marker; caspase9 and decreased Bcl-2 was also found. On the other hand, CAR co-administration with PDD significantly evaded these effects which were confirmed histologically.

Conclusion: CAR could be used as complementary supplements in malnutrition for protection against PDD induced testicular atrophy in male albino rats.

JRAM 2020; 1(2): 96-103

Keywords: Juvenile rats, protein deficient diet, testicular atrophy

Submission date: 21 January 2020

Acceptance date: 15 March 2020

Corresponding author: Omneya Mohamed Kamel, Physiology department, School of Medicine, Newgiza University, Cairo, Egypt Tel: 01279999772, E-Mail: omneya.kamel@ngu.edu.eg

Please cite this article as: Kamel OM, Ramadan BK, Abd Elwahab AH, Mohamed SM ${ }^{2}$, Ali HS. The possible ameliorative effect of carnosine in protein deficient diet induced testicular damage. JRAM 2020; 1(2): 96-103. DOI: 10.21608/jram.2020.22346.1033

\section{INTRODUCTION}

About one billion people worldwide suffer from inadequate protein intake. The problem is so severe especially in developing countries, where up to $30 \%$ of children get too little protein from their diet ${ }^{[1]}$. Protein intake has an important role in development and growth of the male reproductive system. It has been reported that protein malnutrition is hazardous especially to males and this problem is dominant in overpopulated countries ${ }^{[2]}$. Early stages of life are critical for spermatogenesis in male reproductive function because all stages of testicular cells differentiation and maturation happen in neonatal and pre-pubertal periods. Therefore, testicular affection of male newborn might occur due to food restriction during pregnancy and lactation ${ }^{[3]}$.

Studies on nutritional deficiency during childhood and adolescence show that it may cause changes in the tubal diameter and damage the germ cells, also may reduce the production of testosterone hormone ${ }^{[4]}$. In addition, chronic ingestion of low protein diets causes JRAM copyright @ 2020. All rights reserved 
inflammatory responses that leads to excess elaboration of cytokines as interleukins, interferon and tumor necrosis factor $\alpha$ (TNF- $\alpha)$. It also induces formation of reactive oxygen species, decreases the total antioxidant capacity, in addition to poor libido, impotence and infertility ${ }^{[5]}$

Carnosine is dipeptide found endogenously in skeletal muscle and brain; it consists of $\beta$-alanine and L-histidine. The main sources of carnosine in diet are meat and fish [6]. Carnosine supplementation has come into consideration due to evidence of its ergogenic effects ${ }^{[7]}$. Carnosine was found to reduce the oxidative damage, improves the enzymatic and non-enzymatic antioxidant activity and increases the levels of catalase and GSH in tissues. Also it increases the total antioxidant capacity (TAC), reduces malondialdehyde (MDA) and isoprostanes levels of in the brain tissue ${ }^{[8]}$. The present study aimed to clarify the dangerous impact of protein deficient diet on testicular functions in male rats and unwind the possible protective effects of carnosine combined with PDD.

\section{MATERIAL AND METHODS}

Material: Normal protein-energy diet (NPD), containing $16.55 \%$ total protein of $16.04 \mathrm{mJkg}^{-1}$ gross energy, and low protein-energy diet (LPD), containing $6.21 \%$ total protein of $18.11 \mathrm{mJkg}^{-1}$ gross energy diets were prepared [9]. L-carnosine was purchased from Sigma-Aldrich Chemical Co., St. Louis, MO.

\section{Methods:}

Experimental design: Forty juvenile male Wister albino rats were purchased from Al-Nile Pharmaceuticals Company, Cairo, Egypt. They were about 4-5-weeks old and weighing 70-80 g. Rats were kept in laboratory cages, with 12 hours light and -dark cycles for two weeks before the start of the work for acclimatization in the laboratory of Faculty of Medicine for Girls, Al-Azhar University.

Rats were maintained on standard rat chow and water ad libitum. They were randomly divided into four equal groups (10 rats each). Group I, rats received normal balanced chow and saline intraperitoneal (IP) 5 days/week for 75 days and served as normal control group. The second group (PDD group), rats received PDD, which was freshly prepared before use for 75 days and saline IP 5 days/week. Group III (CAR) rats received normal diet and daily carnosine dose of $250 \mathrm{mg} / \mathrm{kg} \mathrm{bw}$, IP 5 days/week for 75 days according to ${ }^{[10]}$. Group IV (CAR-PDD group), rats received daily carnosine dose of $250 \mathrm{mg} / \mathrm{kg}$ bw IP 5 days/week and PDD for 75 days.

Serum and tissue collection: under light anesthesia, blood samples were withdrawn from the retro-orbital plexus by using heparinized capillary tubes, centrifuged at $3000 \times \mathrm{g}$ for $20 \mathrm{~min}$ at $4^{\circ} \mathrm{C}$ (according to the kit instructions) to separate sera, for determination of testosterone, FSH and LH levels. Samples were stored at $-80^{\circ} \mathrm{C}$ until assayed. All animals were subjected to cervical dislocation and both testes were excised. The right testis was used for homogenization and assessment of oxidative stress markers activities, pro-inflammatory cytokines, apoptotic assay and gene expression for caspase 9 and Bcl-2. The left one was used for histopathological examination ${ }^{[11]}$.

Semen evaluation: was done according to Lasley ${ }^{[12]}$ and Amann and Almquist ${ }^{[13] .}$

Tissue preparation of the homogenate: The right testis of each rat was washed and kept in $1 \mathrm{ml}$ of $0.9 \% \mathrm{NaCl}$. Then it was sliced into two parts; the first was homogenized in saline and centrifuged at 20,000 $\times \mathrm{g}$ for $30 \mathrm{~min}$ at $4^{\circ} \mathrm{C}$. The supernatants were collected and stored at $-20^{\circ} \mathrm{C}$ for the assessment of GSH, CAT, TNF$\alpha$. The second part of the right testis was homogenized in Radioimmunoprecipitation (RIPA) buffer, and centrifuged at $10,000 \times \mathrm{g}$ for $10 \mathrm{~min}$ at $4^{\circ} \mathrm{C}$ and the protein supernatants were used for assessment of western blotting of BCL-2 and caspase 9.

\section{Biochemical analysis:}

For assessment of sex hormones (testosterone, LH and FSH) levels, Diagnostic System Laboratories Inc., USA, ELISA kits were used.

Assessment of testicular tissues antioxidant status: Testicular catalase (CAT) activity was estimated according to Clairborne (1995) technique ${ }^{[14]}$. Reduced GSH was measured according to Ceballos-Picot et al. (1992) method ${ }^{[15]}$.

Assessment of testicular inflammation and apoptosis: Testicular inflammation was investigated by measuring TNF- $\alpha$ level using ELISA kits according to research and development (R \& D) systems, USA. Testicular apoptosis was determined by measuring the activity of caspase-9 using Caspase-Glo-9 assay kit in consistent with Promega, Wisconsin, USA.

Western blotting assays: The testicular tissues were homogenized in ice-cold lysis buffer, and the homogenates were centrifuged at $14,000 \times \mathrm{g}$ for $20 \mathrm{~min}$ at $4{ }^{\circ} \mathrm{C}$. Protein contents of samples were assessed according to Bradford method ${ }^{[16]}$.

Histopathological analysis: The left testis was weighed and immersed in Bouin's fixative for 24 hours, then, it was washed in $70 \%$ ethanol and embedded in paraffin. Paraffin blocks were made and different sections at multiple levels were obtained. Slides were prepared and stained by hematoxylin and eosin stains ( $\mathrm{H} \& \mathrm{E})$ and periodic acid-Schiff (PAS) stains for studying the histological changes.

\section{Statistical analysis}

Statistical analysis: was done using statistical package for social science version 12 (SPSS, 12) for windows. 
Quantitative data were expressed as mean \pm standard error of mean (SEM). Analytical statistics was performed using analysis of variance (ANOVA) for comparison of quantitative data of more than two groups followed by Bonferroni post hoc multiple comparison tests. The level of significance was taken at $\mathrm{P} \leq 0.05$.

\section{RESULTS}

1. Effects of PDD, CAR, and their combination on body and testicular weights, and on the serum levels of testosterone, $\mathrm{LH}$ and FSH.
As shown in table 1, there was a significant reduction in body and testicular weights in the PDD-supplemented group in comparison to the control group. CAR-PDD cotreatment returned the body and testicular weights successfully to normal in comparison to the PDD treated group. Treatment with carnosine showed insignificant difference from normal control rats, while when compared with PDD group a significant elevation was observed.

Table 1: Effects of protein deficient diet (PDD), carnosine (CAR), and their combination on body and testicular weights at the end of the experiment

\begin{tabular}{|c|c|c|c|c|}
\hline Animal group & $\begin{array}{c}\text { Group I } \\
\text { (Control group) } \\
\text { Mean } \pm \text { SEM } \\
(\mathbf{N}=\mathbf{1 0})\end{array}$ & $\begin{array}{c}\text { Group II } \\
\text { (protein deficient diet } \\
(\text { PDD) group) } \\
\text { Mean } \pm \text { SEM } \\
(\mathbf{N}=\mathbf{1 0})\end{array}$ & $\begin{array}{c}\text { Group III } \\
\text { (Carnosine (CAR) } \\
\text { group) } \\
\text { Mean } \pm \text { SEM } \\
(\mathbf{N}=\mathbf{1 0})\end{array}$ & $\begin{array}{c}\text { Group IV } \\
\text { (CAR-PDD group) } \\
\text { Mean } \pm \text { SEM } \\
(\mathrm{N}=10)\end{array}$ \\
\hline Body weight (g) & $260 \pm 2.1$ & $170^{\mathrm{a}} \pm 1.01$ & $251^{\mathrm{b}} \pm 1.55$ & $239^{\mathbf{a}, \mathbf{b}} \pm 1.85$ \\
\hline Testicular weight (g) & $1.12 \pm 0.03$ & $0.51^{\mathrm{a}} \pm 0.05$ & $1.19^{b} \pm 0.02$ & $1.01^{b} \pm 0.07$ \\
\hline
\end{tabular}

(a) Significant versus the control group. (b) Significant versus the PDD group.

Regarding to the levels of sex hormones (Figure 1), PDD significantly decreased the serum levels of testosterone and LH compared to control. On the other hand, carnosine treatment showed insignificant change when compared to control rats, while when compared to PDD group a significant elevation was observed. In the CARPDD co-treatment, the decreased levels of these hormones returned nearly to the normal.

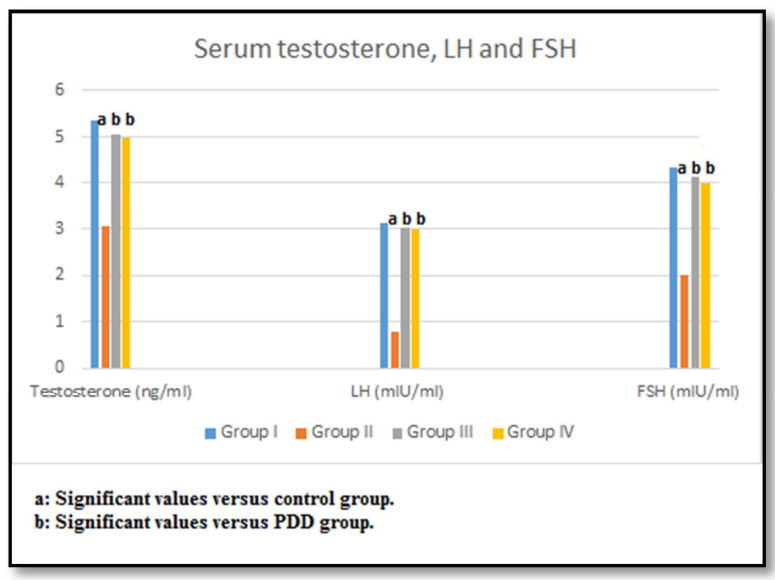

Figure (1): Effects of PDD, CAR, and their combination on serum sex hormone levels, testosterone, luteinizing hormone (LH) and follicle stimulating hormone (FSH). Data are expressed as the mean \pm SEM. $\mathrm{N}$ for each group $=10$. (a) Significant versus the control group. (b) Significant versus the PDD group.

2. Effect of PDD, CAR and their combination on the testicular levels of pro-inflammatory cytokines and antioxidant.

The testicular pro-inflammatory cytokine tumor necrosis factor alpha (TNF- $\alpha$ ), was significantly increased in PDD-treated rats in comparison to control rats (Figure 2). Carnosine supplementation showed insignificant change when compared to the control group while showed significant reduction when compared to PDD group. Carnosine co-administration with PDD for 75 days successfully returned back the elevated cytokine levels to normal in comparison to PDD supplementation.

PDD supplementation for 75 days induced oxidative stress as indicated by significant reductions in catalase (CAT) activity and GSH levels compared to control (Figure 3), while carnosine supplementation showed insignificant change when compared to control and a significant elevation when compared to PDD group. After CAR-PDD supplementation both levels were returned close to the control group. 


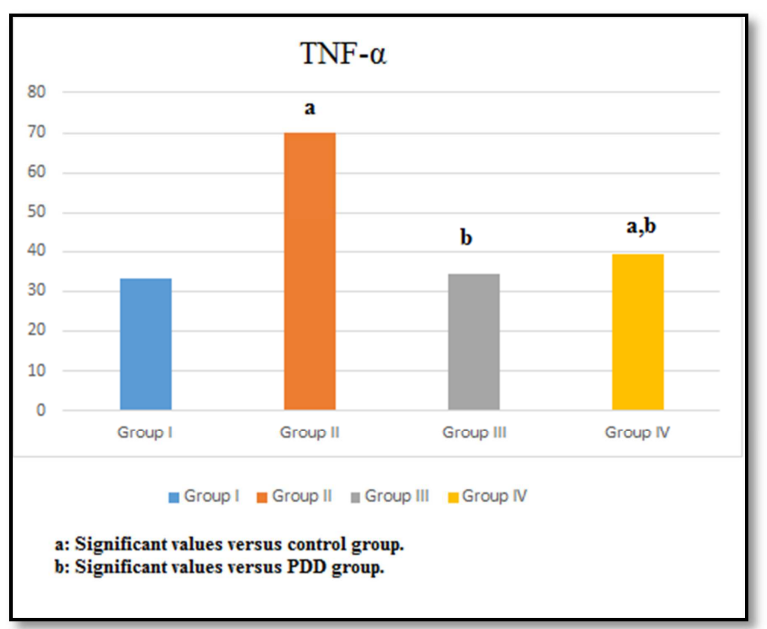

Figure (2): Effects of PDD, CAR, and their combination on testicular levels of tumor necrosis factor alpha (TNF- $\alpha$ ) in experimental groups. Data are presented as the mean \pm SEM. $\mathrm{N}$ for each group $=10$. (a) Significant versus the control group. (b) Significant versus the PDD group.

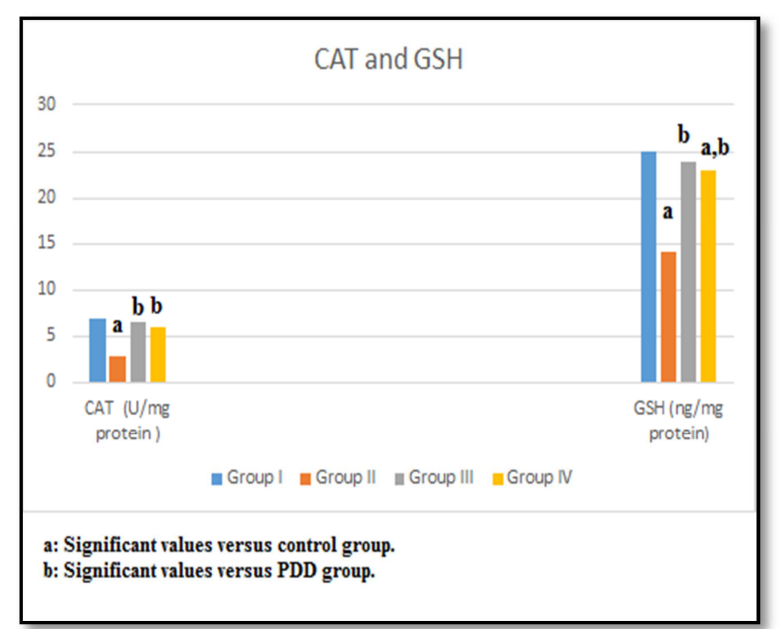

Figure (3): Effects of PDD, CAR, and their combination on testicular levels of catalase (CAT) and glutathione (GSH) (b) in experimental groups. Data are presented as the mean \pm SEM. $\mathrm{N}$ for each group $=10$. (a) Significant versus the control group. (b) Significant versus the PDD group.

3. Effect of PDD, CAR and their combination on the sperm count, viability (Live: Dead ratio) and motility. The sperm motility, sperm count, and viability were significantly reduced in PDD treated rats in comparison to control rats (table 2). CAR-PDD co-treatment returned these levels to normal. Carnosine supplementation to normal rats showed insignificant changes from the control group and statistical significant elevation in comparison to the PDD supplemented group.

Table (2): Effects of protein deficient diet (PDD), Carnosine (CAR), and their combination on percentage of sperm motility, epididymal count $(106 / \mathrm{ml})$ and sperm vitality (Live: Death ratio) of different studied animal groups at the end of the experiment.

\begin{tabular}{|c|c|c|c|c|}
\hline Animal group & $\begin{array}{c}\text { Group I } \\
\text { (Control group) } \\
\text { Mean } \pm \text { SEM } \\
(\mathbf{N}=10)\end{array}$ & $\begin{array}{l}\text { Group II } \\
\text { protein deficient die } 1 \\
\text { (PDD) group) } \\
\text { Mean } \pm \text { SEM } \\
(\mathbf{N}=\mathbf{1 0})\end{array}$ & $\begin{array}{c}\text { Group III } \\
\text { (Carnosine } \\
\text { (CAR) group) } \\
\text { Mean } \pm \text { SEM } \\
(\mathbf{N}=\mathbf{1 0})\end{array}$ & $\begin{array}{c}\text { Group IV } \\
\text { (CAR-PDD group) } \\
\text { Mean } \pm \text { SEM } \\
(\mathbf{N}=10)\end{array}$ \\
\hline Sperm Motility (\%) & $92.04 \pm 3.01$ & $55.50^{\mathrm{a}} \pm 1.59$ & $90.05^{\mathbf{b}} \pm 2.2$ & $87.95^{b} \pm 1.35$ \\
\hline $\begin{array}{l}\text { Caudal epididymal sperm } \\
\text { count }\left(10^{6} / \mathrm{ml}\right)\end{array}$ & $97.12 \pm 3.11$ & $38.95^{\mathrm{a}} \pm 3.65$ & $95.1^{b} \pm 2.53$ & $93.86^{b} \pm 1.95$ \\
\hline $\begin{array}{l}\text { Sperm vitality } \\
\text { (Live: Death ratio) }\end{array}$ & $14.01 \pm 0.18$ & $6.15^{\mathrm{a}} \pm 1.35$ & $13.99^{b} \pm 0.14$ & $13.32 \quad{ }^{b} \pm 0.12$ \\
\hline
\end{tabular}

(a) Significant versus the control group. (b) Significant versus the PDD group.

4. Effects of protein deficient diet (PDD), carnosine (CAR), and their combination on the caspase-9 activity and $B$ cell lymphoma-2 (Bcl-2) expression in testicular homogenate. Significant elevation in levels of caspase-9 levels, while the levels of Bcl-2 levels were reduced significantly compared to control rats in PDDsupplemented rat testes homogenate (Figure 4). An insignificant change was observed in CAR group when compared to control, while a significant elevation of Bcl2 and reduction of caspase-9 was observed when compared to PDD group. On the other hand CAR-PDD co-treatment significantly elevated Bcl-2 levels and reduced caspase-9 levels in comparison to PDD group. 


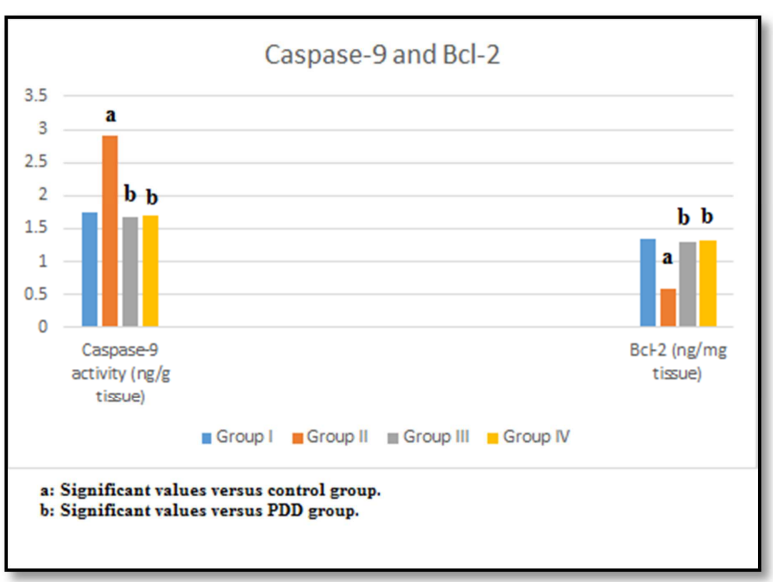

Figure 4: Comparison between caspase 9 and Bcl-2 activities of different studied animal groups at the end of the experiment. Data are presented as the mean \pm SEM. $\mathrm{N}$ for each group $=10$. (a) Significant versus the control group. (b) Significant versus the PDD group.
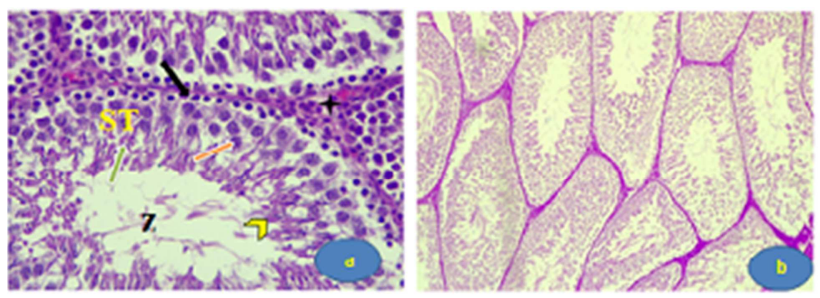

control
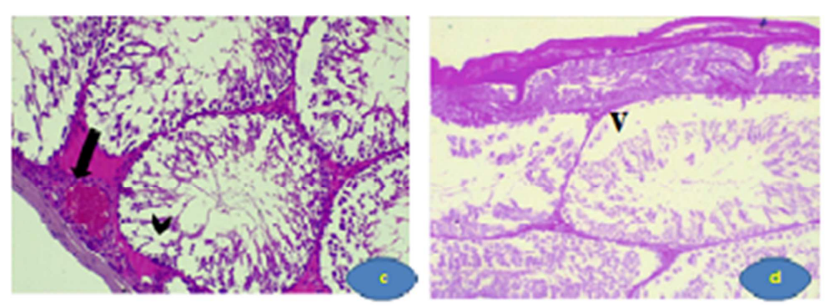

PDD
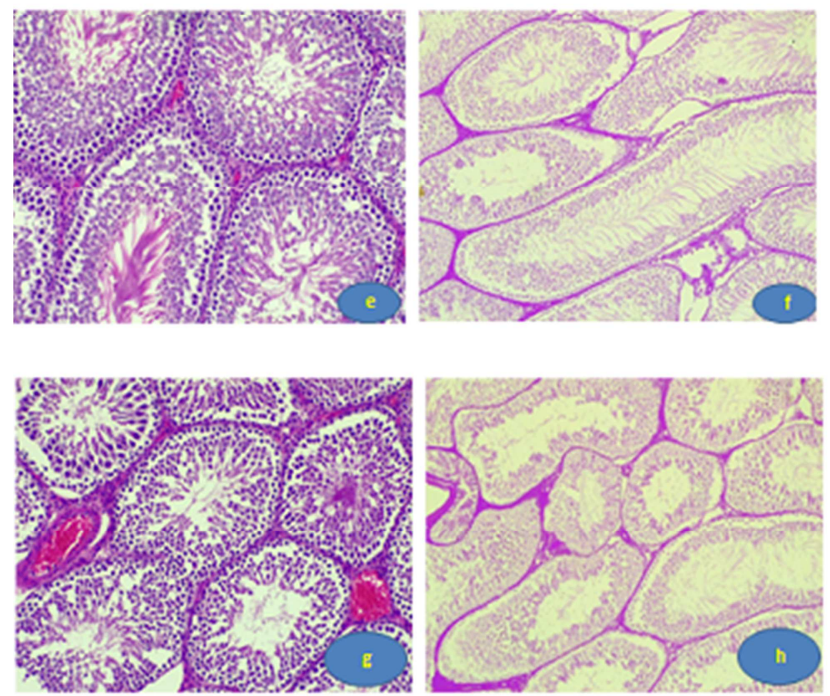

CAR

\section{Histopathology results \\ Light microscopy examination (Figure 5)}

When compared to the normal control rat, rat testes of PDD group (c), stained with H\&E- (a) and PAS stain (b), showed interepithelial vacuoles in seminiferous tubules, distortion of the spermatogenic cells. There were congested dilated blood vessels with cellular infiltration in between the tubules. (d) Massive intense PAS positive reaction in connective tissue in between seminiferous tubules and weak reaction in the basement membrane of the degenerated tubules. CAR group (e-f): showing normal structure of seminiferous tubules as the control.

In the CAR-PDD treated group (g-h), the architecture of the testis was more likely similar to that of the control. Some congested dilated blood vessels with cellular infiltration in-between the tubules were still seen.

Control group: (a) Seminiferous tubules of lined with spermatogonia cells (black arrow), spermatocyes (orange arrow), sperms (yellow arrow head) and spermatids (green Arrow). Leydig cell and connective tissue containing blood vessels are seen in between the tubules (astras) (H\&E X 400). (b) Moderate PAS positive reaction in connective tissue in between seminiferous tubules and weak reaction in the basement membrane of the tubules (PAS stain X 200).

PDD group: (c) Seminiferous tubules with interepithelial vacuoles (arrow head), distortion of the spermatogenic cells. There is congested and dilated blood vessels with celluar infilteration in between the tubules (arrow) (H\&E x 400). (d) Massive intense PAS positive reaction in connective tissue in between seminiferous tubules and week reaction in the basement membrane of the degenerated tubules (PAS stain X 200).

CAR group: (e) Some seminiferous tubules lined with spermatogenic cells, the lumen filled with sperms. The tubules of CAR group are more or less similar to control group (H\&E X 400). (f) Moderate PAS positive reaction in connective tissue in between seminiferous and in the basement membrane of the tubules. It is more or less similar to control group (PAS stain X 400).

CAR-PDD group: (g) CAR-PDD group showing seminiferous tubules lined with spermatogenic cells and the lumen filled with sperms. There are congested and dilated blood vessels with cellular infiltration in between the tubules. Leydig cell and connective tissue are seen in between the tubules (H\&E X 400). (h) Moderate PAS positive reaction in both connective tissue in between seminiferous tubules and the basement membrane in the CAR-PDD group (PAS stain X 200).

Figure (5) Photomicrographs of testis sections from all experimental groups

DISCUSSION 
Protein deficiency has become a great problem among youngsters, adolescents and adults ${ }^{[17]}$. Its potential progression to serious diseases including male reproductive system was proven in the present study which caused significant inflammation, oxidative stress and apoptosis. Protein deficient diet supplementation for seventy five days to rats in the present work caused significant reduction of both body and testicular weights in comparison to the group supplemented by normal protein diet. These results were supported by the studies of Soenen and Chapman [18], Macartney et al. ${ }^{[19]}$, Nakamura et al., ${ }^{[20]}$. Possible explanation was reported by Martens et al. ${ }^{[21]}$ who stated that low protein diet increases the energy expenditure by increasing the sympathetic flux through $\beta$ adrenergic receptor signaling to brown adipose tissue (BAT) by increasing mitochondrial activity and thermogenesis. The reduction of testicular weight in the present work was also consistent and explained by Ozegbe and Omirinde ${ }^{[9]}$ who stated that protein deficiency caused epididymal structural changes, decreased weights of sex glands and general affection of growth. Reduction of both body and testicular weights was ameliorated by carnosine administration. Snyder et al. ${ }^{[22]}$ related this improvement to stimulation of carnosine formation in the skeletal muscles. Another explanation was stated by Baye et al. [23] who reported that carnosine enhances insulin sensitivity in muscles and adipose tissues which helps the anabolic function of insulin and building up of muscles. ALaqeel, ${ }^{[24]}$ attributed the beneficial effects of carnosine on keeping testicular weight to the antioxidant and antiinflammatory activities of carnosine.

Testosterone hormone has a great role in spermatogenesis, motility and maturation of sperms. Any decrease in testosterone levels can unfavorably affect testicular activity ${ }^{[25]}$. Findings of the present study showed that protein deficient diet (PDD) induced reduction in serum levels of testosterone, $\mathrm{LH}$ and $\mathrm{FSH}$. These results were in consistence with the studies of ${ }^{[19,20,26,27]}$, and explained by Karaca et al. ${ }^{[28]}$ that this reduction is due to decrease of endocrine activity of the testes and this leads to the hindrance of growth and secretory function of the male reproductive organs. This was confirmed by the histopathological findings of this work in which disintegration of Leydig cells, degenerated and declined spermatogonia, atrophied seminiferous tubules, degenerated spermatocytes and spermatids were observed. These changes lead to impaired spermatogenesis and deterioration of sperm characteristics. Another explanation was reported by Zirkin and Tenover ${ }^{[29]}$ that this reduction of sex hormone levels is due to oxidative stress-induced damage of the interstitial cells of Leydig that are responsible for testosterone secretion in the presence of LH.

The current work suggests an important link between PDD and testicular inflammation with oxidative stress changes, as evinced by elevated testicular TNF- $\alpha$ level, reduced catalase activity and GSH levels with decrease in sperm motility, count and vitality. This association was supported by the studies of Ramonda et al. ${ }^{[30]}$, Dong et al. ${ }^{[1]}$ and van Zutphen et al. ${ }^{[32]}$. Somade et al. ${ }^{[33]}$ stated that the oxidative stress is highly related to mediators of inflammation, both playing an important role in pathogenesis of testicular damage. These disturbances were effectively annulled by CAR. These results were in agreement with Baye et al. ${ }^{[23]}$, who reported that carnosine can reduce cytokines and act as a free radical scavenger. The anti-inflammatory and antioxidant mechanisms of carnosine were explained by Abbasoğlu et al. ${ }^{[34]}$ who reported that, iron ions of metals play an active role in many metabolic processes, activating free-radical processes and carnosine has the ability to bind them and regulate their levels and this can confirm carnosine's antioxidant property.

As regards the apoptotic state, our findings revealed that, carnosine co-administration with PDD significantly reduced the caspase- 9 apoptosis pathway and elevated the anti-apoptosis factor $\mathrm{Bcl}-2$. These results were supported by Haeri et al. ${ }^{[35]}$, who stated that testicular malfunction because of gamma-radiation, can be restored by carnosine via its anti-apoptotic action. Also, Riedl et al. ${ }^{[36]}$ reported that the kidney affection in diabetes mellitus including the apoptosis of glomerular cells and loss of podocytes could be prevented and diminished by carnosine. They explained their results that, carnosine has a great role in numerous physiological processes, including enzyme regulation and $\mathrm{pH}$ buffering, these functions could contribute to the cytoprotective effect of carnosine.

\section{CONCLUSION}

PDD has destructive effect on the testes in juvenile male rats, while CAR co-administration with PDD supplementation can protect from the oxidative damage and apoptosis in the testes induced by PDD, and can protect the normal testicular tissues histological structure. The benefit of CAR as anti-inflammatory, antioxidant, antiapoptotic and hence testicular hypofunction, can encourage further studies for its use as a supplement in cases of protein deficiency malnutrition.

\section{Financial support:}

No financial support from any institution only we depend on ourselves financially.

\section{Conflict of interest:}

The authors declare that there is no conflict of interest regarding the publication of this paper.

\section{REFERENCES}

1. Wu G, Fanzo J, Miller D, Pingali P, Post M, Steiner $\mathbf{J}$ et al. Production and supply of highquality food protein for human consumption: sustainability, challenges, and innovations, Ann N Y Acad Sci 2014; 1321:1-19. 
2. Ahmed-Farid O, Nasr M, Rania F, Bakeer F. Beneficial effects of curcumin nanoemulsion on spermatogenesis and reproductive performance in male rats under protein deficient diet model: enhancement of sperm motility, conservancy of testicular tissue integrity, cell energy and seminal plasma amino acids content. J Biomed Sci 2017; 24:66.

3. de Oliveira $\mathbf{J}$, da Silva $\mathbf{V}$. Protein restriction during intrauterine and lactation periods: effects on testicular development in pre-puberty rats. Acta Sci Biol Sci; 2015; 37(1):107-112.

4. Rodríguez-González $\mathbf{G}$, Viguerasvillaseñor $\mathbf{R}$, Millán S, Moran N, Trejo R, Nathanielsz P, et al. Maternal protein restriction in pregnancy and/or lactation affects seminiferous tubule organization in male rat offspring. J Dev Orig Hth Dis 2012; 3(5):16.

5. Muzi-Filho H, Bezerra C, Souza A, Boldrini L, Takiya C, Oliveira F, et al. Under nutrition affects cell survival, oxidative stress, $\mathrm{Ca} 2+$ handling and signaling pathways in vas deferens, crippling reproductive capacity. PLOS ONE 2013; 8 (7) e69682.

6. Menon K, Mousa A , de Courten B. Effects of supplementation with carnosine and other histidinecontaining dipeptides on chronic disease risk factors and outcomes: protocol for a systematic review of randomised controlled trials. Br Med J Open 2018; 8:e020623.

7. Saunders B, Elliott-Sale K, Artioli G, Swinton P, Dolan E, Roschel $\mathbf{H}$, et al. $\beta$-Alanine supplementation to improve exercise capacity and performance: A systematic review and metaanalysis. Br J of Sports Med 2017; 51: 658-669.

8. Devyatov A, Fedorova T, Stvolinsky S, Ryzhkov I, Riger N, Tutelyan V. Study of the neuroprotective effects of carnosine in an experimental model of focal cerebral ischemia/reperfusion. Biomed Khim 2018; 64(4): 344-348.

9. Ozegbe $\mathbf{P}$, Omirinde J. Comparative morphophysiological evaluation of the testis of adult Wistar rats fed low protein-energy diet and dosed with aqueous extracts of Cuscuta australis. Niger $\mathbf{J}$ Physiol Sci 2012; 149 - 155 .

10. Aydin A, Küçükgergin C, Çoban J, Doğan-Ekici I, Doğru-Abbasoğlu S, Uysal M, et al. Carnosine prevents testicular oxidative stress and advanced glycation end product formation in D-galactoseinduced aged rats. Andrologia 2018; 50:e12939.

11. Harleman J. Testicular toxicity: Regulatory guidelines-The end of formaldehyde fixation. Toxicol Pathol 1997; 25:414.

12. Lasley J, Mayer D , Bogart R. Influence of reproductive hormones upon growth in ovariectomized and normal female rats, Endocrinology 1944; 35(3):173-181.
13. Amann R, Almquist J. Reproductive capacity of dairy bulls. I. Technique for direct measurement of gonadal and extra-gonadal sperm reserves. J Dairy Sci, 1961; 44:1537-1543.

14. Clairborne A. Catalase activity. In: Greewald AR, editor. Handbook of methods for oxygen radical research. Florida: CRC Press 1995; 237-242.

15. Ceballos-Picot $I$, Trivier $J$, Nicole $A$, Sinet $P$, Thevenin M. Age-correlated modifications of copper-zinc superoxide dismutase and glutathionerelated enzyme activities in human erythrocytes. Clin Chem 1992; 38(1):66-70.

16. Bradford M. A rapid and sensitive method for the quantitation of microgram quantities of protein utilizing the principle of protein-dye binding. Anal Biochem, 1976; 72:248-54.

17. Khan A, Khan S, Jan A , Khan M. Health complication caused by protein deficiency. J Food Sci Nutr 2017; 1(1):1-2.

18. Soenen S, Chapman I. Body weight, anorexia, and undernutrition in older people. J Am Med Dir Assoc 2013; 14(9): 642-648.

19. Macartney E, Crean A, Nakagawa $S$, Bonduriansky R. Effects of nutrient limitation on sperm and seminal fluid: a systematic review and meta-analysis. Biol Rev 2019; 94(5): 1722 - 1739.

20. Nakamura Y, Hatano M, Iwashita T, Shimizu T, Ogawa T, Kanozawa K, et al. Protein Energy Wasting and Sarcopenia in Dialysis Patients. Contrib Nephrol 2018; 196:243-249.

21. Martens E, Tan S, Dunlop M, Mattes $\mathbf{R}$, Westerterp-Plantenga M. Protein leverage effects of beef protein on energy intake in humans. Am J Clin Nutr 2014; 99: 1397-1406.

22. Snyder G, Gaylord T, Barrows F, Overturf K, Cain K, Hill R, et al. Effects of carnosine supplementation to an all-plant protein diet for rainbow trout (Oncorhynchus mykiss). Aquaculture 2012; 338-341: 72-81.

23. Baye E, Menon $K$, de Courten M, Earnest A, Cameron J, de Courten B, et al. Does supplementation with carnosine improve cardiometabolic health and cognitive function in patients with prediabetes and type 2 diabetes? study protocol for a randomised, double blind, placebocontrolled trial. Br Med J Open 2017; 7:e017691.

24. ALaqeel $\mathbf{N}$. Carnosine Treatment Attenuates Testicular Toxicity Induced by Arsenic in Rats. Life Sci J 2017; 14(2).

25. Darbandi M, Darbandi S, Agarwal A, Sengupta P, Durairajanayagam D, Henkel R, et al. Reactive oxygen species and male reproductive hormones. Reprod Bio Endocrin 2018; 16,87.

26. Gaunitz F , Hipkiss A. Carnosine and cancer: a perspective. Amino Acids 2012; 43:135-42.

27. Chinoy A, Mehta D , Ahmedabad D. Effects of fluoride ingestion with protein deficient or protein 
enriched diets on sperm function of mice. Research report. Fluoride 2006; 39(1)11-16.

28. Karaca F, Dönmez M , Karslı M. Effects of protein deficiency on testosterone levels, semen quality and testicular histology in the developing male rat. Scand J Lab Anim Sci, 2003; 1(30): 7-13.

29. Zirkin B and Tenover J. Aging and declining testosterone: Past, present, and hopes for the future. J Androl 2012; 33: 1111-1118.

30. Ramonda R, Foresta C, Ortolan A, Bertoldo A, Oliviero F, Lorenzin $\mathbf{M}$. Influence of tumor necrosis factor $\alpha$ inhibitors on testicular function and semen in spondyloarthritis patients. Fertil Steril 2014; 101(2):359-65.

31. Dong $H$, Wu D, Xu S, Li Q, Fang $Z$, Che L. Effect of dietary supplementation with amino acids on boar sperm quality and fertility. Anim Reprod Sci 2016; 172 (4):182-189.

32. van Zutphen T, Ciapaite J, Bloks V, Ackereley C, Gerding A , Jurdzinski A. Malnutrition-associated liver steatosis and ATP depletion is caused by peroxisomal and mitochondrial dysfunction. $\mathbf{J}$ Hepatol 2016; 65(6):1198-208.
33. Somade O, Ajayib B, Safiriyua O, Oyabunmia S,Akamoa J. Renal and testicular up-regulation of pro-inflammatory chemokines (RANTES and CCL2) and cytokines (TNF- $\alpha$, IL-1 $\beta$, IL-6) following acute edible camphor administration is through activation of NF-kB in rats. Toxicol Rep 2019; 6: 759-767.

34. Abbasoğlu L, Kalaz E, Soluk-Tekkeşin M, Olgaç V, Doğru-Abbasoğlu S, Uysal M. Beneficial effects of taurine and carnosine in experimental ischemia/reperfusion injury in testis. Pediatr Surg Int 2012; 28: 1125-1131.

35. Haeri S, Rajabi H, Fazelipour S, Hosseinimehr S. Carnosine mitigates apoptosis and protects testicular seminiferous tubules from gamma-radiation-induced injury in mice. Andrologia 2014; 46(9):1041-6.

36. Riedl E, Pfister F, Braunage M, Brinkkötter P, Sternik P, Deinzer M, et al. Carnosine prevents apoptosis of glomerular cells and podocyte loss in STZ diabetic rats. Cell Physiol Biochem 2011; 28:279-288. 


\section{الملخص العربي}

الاثار التحسينية المحتملة للكارنوزين على ضرر الخصية الناتج عن نظام غذائي ناقص البروتين

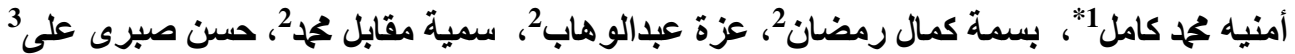

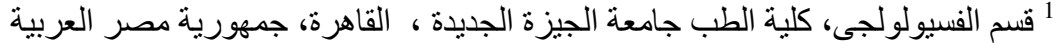

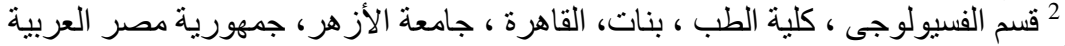

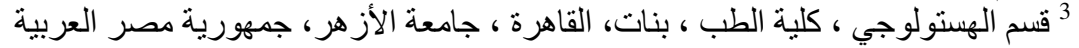

الخلفية: لا يزال سوء التغذية الناجم عن نقص البروتين والسعر ات الحرارية يشكل مصدر قلق كبير في جميع أنحاء العالم وخاصة في

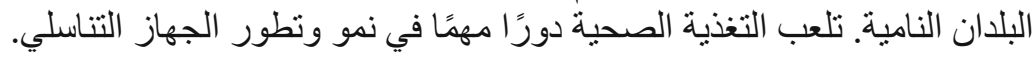

الهُف: تهذف الدراسة الحالية إلى دراسة الفعالية الوقائية المحتملة للكارنوزين على ضمور الخصية الناجم عن نقص البروتين، وضمور الحيو انات المنوية المضطرب ، و وانخفاض الأداء التناسلي لألى ذكور الفئران.

الطرق: تم تخصيص أربعين فئر ان ذكور من ألبينو الأحداث في أربع مجموعات متساوية ؛ كل مجمو عة هي 10 فئر ان (أ) مجموعة

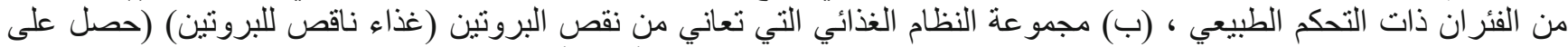

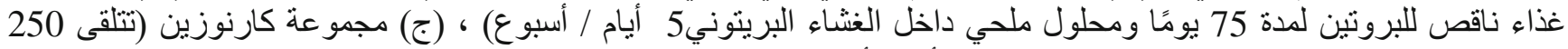

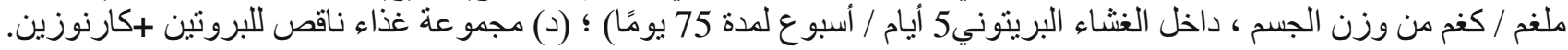
النتائج: تسبب الغذاء ناقص البروتين في انخفاض أوزان الجسم والخصية ، و إجراء تغييرات في الهرمونات الجنسية ونوعية

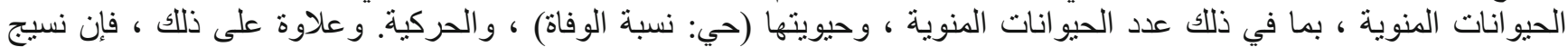

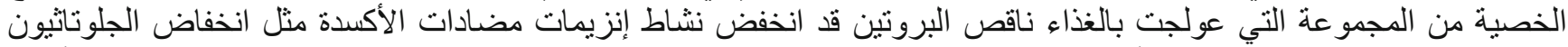

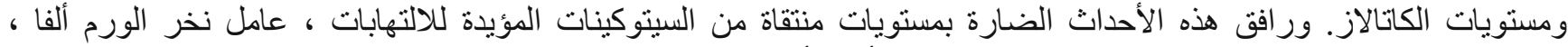

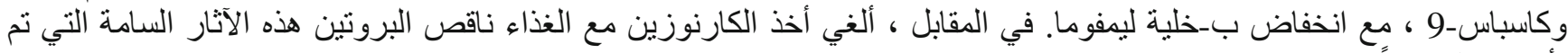

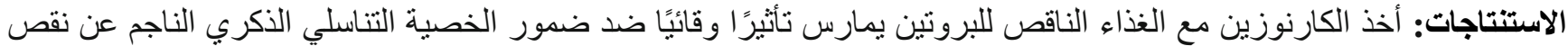

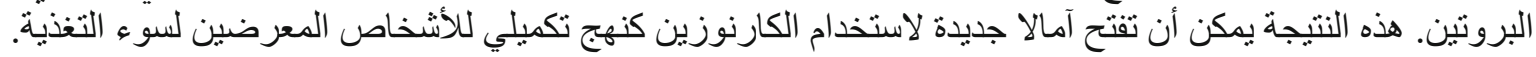

الكلمات المفتاحية: غذاء ناقص للبروتين ، ضمور الخصية ، كاسباس-9 ، -خلية ليمفوما.

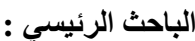
الأسم: أمنيه محمدئ كاملـ قسم الفسيولوجي, كلية الطب جامعة الجيزة الجديدة ، القاهرة ، جامعة الأزهر، جمهورية مصر العربية

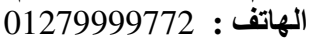
البريد الإكتروني: 